\title{
Prevalence of virulence and cytolethal distending toxin (CDT) genes in thermophilic Campylobacter spp. from dogs and humans in Gyeongnam and Busan, Korea
}

\author{
Hyun-Ho Cho' ${ }^{1}$, Sang-Hyun Kim², Wongi Min ${ }^{3}$, Bok-Kyung Ku${ }^{1}$, Yong-Hwan Kim ${ }^{3}$ ** \\ ${ }^{1}$ Animal, Plant and Fisheries Quarantine and Inspection Agency, Anyang 430-757, Korea \\ ${ }^{2}$ Viral infectious Disease Research Center, Korea Research Institute of Bioscience \& Biotechnology, Daejeon 505-860, Korea \\ ${ }^{3}$ College of Veterinary Medicine, Research Institute of Life Science, Institute of Animal medicine, Gyeongsang National University, \\ Jinju 660-701, Korea
}

(Received: August 1, 2013; Revised: March 3, 2014; Accepted: March 10, 2014)

\begin{abstract}
The prevalence of thermophilic Campylobacter (C.) spp. in stray, breeding, and household dogs was 25.2, 12.0, and $8.8 \%$, respectively. C. jejuni and C. upsaliensis were the predominant Campylobacter spp. from household dogs. $c d t \mathrm{~A}, c d t \mathrm{~B}$, and $c d t \mathrm{C}$ were detected by PCR in all isolates. Despite the high cytolethal distending toxin (CDT) gene prevalence, only $26(31 \%) C$. jejuni strains and one $(15.3 \%) C$. coli strain showed evidence of CDT production in HEp-2 cell cytotoxicity assays. Virulence-associated genes detected in the $C$. jejuni and $C$. coli isolates were $c a d \mathrm{~F}$, $d n a \mathrm{~J}, f l a \mathrm{~A}, r a c \mathrm{R}, c i a \mathrm{~B}, \operatorname{iam} \mathrm{A}, p l d \mathrm{~A}, v i r \mathrm{~B} 11, c e u \mathrm{E}$, and $d o c \mathrm{C} . c a d \mathrm{~F}, d n a \mathrm{~J}, f l a \mathrm{~A}$, and $c e u \mathrm{E}$ were found in all $C$. jejuni and $C$. coli isolates. When detecting Guillain-Barré syndrome-associated genes (galE, cgtB, and wlaN), galE was identified in all isolates. However, $c g t \mathrm{~B}$ and wla $\mathrm{N}$ were more prevalent in $C$. jejuni isolates from humans than those from dogs. Adherence and invasion abilities of the $C$. jejuni and $C$. coli strains were tested in INT-407 cells. A considerable correlation (adjusted $R^{2}=0.678$ ) existed between adherence and invasion activities of the Campylobacter spp. isolates.
\end{abstract}

Keywords : adherence/invasion ability, Campylobacter spp., dog, Guillain-Barré syndrome-associated genes, virulence genes

\section{Introduction}

The genus Campylobacter comprises 16 species of Campylobacter $(C$.) jejuni and 12 species of $C$. coli those have been associated with diseases over $95 \%$ of Campylobacter infections in humans [20]. The isolation rate for C. lari was less than $1 \%$ among the thermophilic Campylobacter spp. The others, such as C. upsaliensis and C. fetus are only occasionally seen in clinical isolates [20].

Campylobacter spp. are important causative agents for gastrointestinal infections in the industrialized and developing countries [1,8]. Clinical signs include abdominal pain, fever, malaise, nausea and vomiting. Recently Campylobacter enteritis has been identified as an important risk factor for the development of inflammatory bowel disease [13]. In addition, extra-intestinal Campylobacter-associated diseases are polyarthragia (reactive arthritis), Guillain-Barré syndrome (GBS), and Miller-Fisher syndrome [10].

Campylobcter spp. are part of the normal intestine flora of wild, domesticated animals and birds. One particular impor- tance to humans is their colonization in animals for food production, including poultry, cattle, sheep, and swine [9]. The household dog has been identified as a risk factor for human campylobacteriosis [11, 31]. Most dogs are asymptomatic when they serve as reservoirs in shedding Campylobacter spp. into their feces. Therefore, contact with the pets has been shown to be a risk factor for Campylobacter infections in humans and actual transmission has been demonstrated $[15,29]$.

However, virulence mechanisms underlying Campylobacter infections are not fully elucidated although flagellamediated motility, adhesion to intestinal mucosa, invasion and production of enterotoxin have been identified as virulence determinants [32]. A number of putative virulence and toxin genes have been studied, including flaA, $c a d \mathrm{~F}, \mathrm{rac} \mathrm{R}$, $\operatorname{cia} \mathrm{B}$, and $i a m \mathrm{~A}$ genes that involved in adhesion and colonization of the host's intestine [17]; ceuE gene which encodes a binding-protein transport system for the siderophore enterochelin [14]; $c d t$ gene cluster encoding a cytolethal distending toxin $(\mathrm{CDT})$ consists of three adjacent genes $(c d t \mathrm{~A}, c d t \mathrm{~B}$,

*Corresponding author

Tel: +82-55-772-2345, Fax: +82-55-772-2808/2349

E-mail: yho157@gnu.ac.kr 
and $c d t \mathrm{C})$. The CDT toxin is composed of CdtB protein as the enzymatically active subunit and two hetero-dimeric subunits (CdtA and $\mathrm{CdtC}$ ), which are responsible for the holotoxin binding to cell membrane [3].

Lipo-oligosaccharides (LOS) are thought to be a critical factor in the triggering of the Guillain-Barré syndrome (GBS) and Miller-Fisher syndrome neuropathies after $C$. jejuni infection [10]. Linton et al. [21] demonstrated the wla $\mathrm{N}$ gene product as a $\beta-1,3$ galactosyltransferase responsible for biosynthesis of host-mimicking LOS structure.

The aim of this study was to investigate the isolation rates of Campylobacter spp. from household, stray, and breeding dogs in Gyeongnam and Busan areas. Furthermore, prevalence of putative virulence genes was detected by PCR in the isolates of Campylobacter spp. from dogs and humans. The adherence/invasion ability of Campylobacter bacteria was evaluated by a gentamicin-treated INT407 cell assay. The expression of CDT activity in the culture supernatants of Campylobacter spp. isolates was tested for cytotoxicity assay with HEp-2 cells. The prevalence of GBS-associated genes $(g a l \mathrm{E}, \operatorname{cgt} \mathrm{B}, w l a \mathrm{~N})$ that are involved in the LOS biosynthesis in $C$. jejuni was detected by PCR with the isolates from dogs and humans.

\section{Materials and Methods}

\section{Source of samples}

A total of 460 fecal samples (1 g) were collected from three groups of dogs in Gyeongnam and Busan areas from January 2009 to April 2010 for isolation of thermophilic Campylobacter spp.

Group 1: A total of 274 fecal specimens $(1 \mathrm{~g})$ from household dogs were collected at local veterinary clinics located at Gyeongnam and Busan areas. Group 2: one gram of fecal samples from 103 stray dogs was collected from municipal animal shelter in the western Gyeongnam areas. Group 3: one gram of fecal sample from 83 breeding dogs was collected in the western Gyeongnam areas.

Ten $\mathrm{mL}$ of Preston selective enrichment broth (Oxoid, Germany) containing each one gram of fecal sample in ice box was carried to laboratory within $8 \mathrm{~h}$ and used for isolation immediately.

\section{Thermophilic Campylobacter spp. isolation}

The broth emulsified by brief vortexing was incubated at $42^{\circ} \mathrm{C}$ for 2 days in a microaerobic atmosphere $\left(5 \% \mathrm{O}_{2}, 10 \%\right.$ $\mathrm{CO}_{2}, 85 \% \mathrm{~N}_{2}$ ). One loopful of broth was streaked to modified CCDA Preston agar (Oxoid CM 739 plus selective supplement SR155; Oxoid) and the agar plates were incubated same culture condition indicated above. Typical Campylobacter colonies on modified CCDA Preston agar were transferred to blood agar plate and the plates were incubated at the same culture condition for $48 \sim 72 \mathrm{~h}$.

Three colonies of presumptive Campylobacter bacteria grown on blood agar plate were identified at species level on the basic of phase contrast microscope (spiral shape and corkscrew movement), catalase, oxidase, rapid $\mathrm{H}_{2} \mathrm{~S}$ production, growth at $25^{\circ} \mathrm{C}$ and $42^{\circ} \mathrm{C}$, hippurate hydrolysis and susceptibility to nalidixic acid and cephalothin. C. jejuni ATCC 33560 and $C$. coli ATCC 33559 were used as reference strains.

Multiplex polymerase chain reaction (mPCR) was used to differentiate major species of campylobacters. The genomic DNA of Campylobacter spp. isolates was extracted using a DNA isolation kit (QIAamp DNA mini; Qiagen, Germany) by the manufacturer's instruction. Identification of Campylobacter spp. was performed by using MultiPerfect Campylobacter spp. PCR kit (G\&P Life Science, Korea) containing specific primers for C. jejuni, C. coli, C. lari, C. fetus, and C. upsaliensis.

Forty-six C. jejuni and 4 C. coli isolated from humans with diarrhea in Seoul areas during 2008 2009 were kindly provided by Korea National Institute of Health for comparison. All isolates were stored in liquid nitrogen at $-150^{\circ} \mathrm{C}$.

\section{Detection of CDT genes by PCR}

Genomic DNA was amplified by mPCR to confirm the presence of CDT genes ( $c d t \mathrm{~A}, c d t \mathrm{~B}$ and $c d t \mathrm{C})$. All PCR reactions were performed in a total volume of $25 \mu \mathrm{L}$, containing $12.5 \mu \mathrm{L}$ GoTag Green Master Mix, 2× (Promega, USA), $1 \mu \mathrm{L}$ upstream and downstream primer (GenoTech, Korea), 2 $\mu \mathrm{L}$ DNA template, and $8.5 \mu \mathrm{L}$ nuclease-free water. Primer and PCR condition are listed in Table 1. PCR was performed in a DNA Thermal Cycler (Eppendorf, Germany) and PCR amplicons were analysed by horizontal electrophoresis using $1.5 \%$ agarose gel, with a $100 \mathrm{bp}$ molecular weight ladder,

Table 1. PCR primers and condition used for detection of CDT genes

\begin{tabular}{|c|c|c|c|c|c|c|c|}
\hline $\begin{array}{l}\text { Target } \\
\text { gene }\end{array}$ & Primers & $\begin{array}{l}\text { Size } \\
\text { (bp) }\end{array}$ & Sequence $\left(5^{\prime}\right.$ to $\left.3^{\prime}\right)$ & \multicolumn{3}{|c|}{ Condition } & Reference \\
\hline \multirow{2}{*}{$c d t \mathrm{~A}$} & GNW & \multirow{2}{*}{165} & GGAAATTGGATTTGGGGCTATACT & $94^{\circ} \mathrm{C}$ & $15 \mathrm{~min}$ & denaturation & \multirow{6}{*}{$\begin{array}{l}\text { Pickett } \\
\text { et al. }\end{array}$} \\
\hline & IVH & & ATCACAAGGATAATGGACAAT & $94^{\circ} \mathrm{C}$ & $1 \mathrm{~min}$ & & \\
\hline \multirow{2}{*}{$c d t \mathrm{~B}$} & VAT2 & \multirow{2}{*}{495} & GTTAAAATCCCCTGCTATCAACCA & $42^{\circ} \mathrm{C}$ & $2 \mathrm{~min}$ & 30 cycles & \\
\hline & WMI-R & & GTTGGCACTTGGAATTTGCAAGGC & $72^{\circ} \mathrm{C}$ & $3 \mathrm{~min}$ & & \\
\hline \multirow{2}{*}{$c d t \mathrm{C}$} & WMI-F & \multirow{2}{*}{555} & TGGATGATAGCAGGGGATTTTAAC & $72^{\circ} \mathrm{C}$ & $5 \mathrm{~min}$ & extension & \\
\hline & LPF-X & & TTGCACATAACCAAAAGGAAG & $8^{\circ} \mathrm{C}$ & ever & & \\
\hline
\end{tabular}

CDT genes: cytolethal distending toxin genes. 
Table 2. Primers used for detection of adherence, invasion and GBS-associated genes by PCR

\begin{tabular}{|c|c|c|c|c|c|}
\hline $\begin{array}{l}\text { Target } \\
\text { gene }\end{array}$ & & Primers & $\begin{array}{l}\text { Size } \\
\text { (bp) }\end{array}$ & Sequence (5' to $\left.3^{\prime}\right)$ & References \\
\hline \multirow{9}{*}{$\begin{array}{c}\text { Adherence } \\
\text { and } \\
\text { invasion- } \\
\text { associated genes }\end{array}$} & $\operatorname{cia} \mathrm{B}$ & $\begin{array}{c}c i a \mathrm{~B}-403 \\
c i a \mathrm{~B}-1373\end{array}$ & 986 & $\begin{array}{l}\text { TTTTTATCAGTCCTTA } \\
\text { TTTCGGTATCATTAGC }\end{array}$ & Datta et al. [9] \\
\hline & $\operatorname{iam} \mathrm{A}$ & $\begin{array}{l}c i a 3 \mathrm{f} \\
c i a 5 \mathrm{r}\end{array}$ & 518 & $\begin{array}{l}\text { GCACAAAATATATCATTACAA } \\
\text { TTCACGACTACTATGAGG }\end{array}$ & Müller et al. [22] \\
\hline & $c a d \mathrm{~F}$ & $\begin{array}{l}c a d \mathrm{~F}-\mathrm{F} 2 \mathrm{~B} \\
c a d \mathrm{~F}-\mathrm{R} 1 \mathrm{~B}\end{array}$ & 400 & $\begin{array}{l}\text { TTGAAGGTAATTTAGATATG } \\
\text { CTAATACCTAAAGTTGAAAC }\end{array}$ & Konkel et al. [17] \\
\hline & vir $\mathrm{B} 11$ & $\begin{array}{l}\operatorname{Vir} \mathrm{B} 11 \mathrm{~F} \\
\operatorname{Vir} \mathrm{B} 11 \mathrm{R}\end{array}$ & 709 & $\begin{array}{l}\text { GAACAGGAAGTGGAAAAACTAGC } \\
\text { TTCCGCATTGGGCTATATG }\end{array}$ & Bacon et al. [4] \\
\hline & $\operatorname{doc} \mathrm{C}$ & $\begin{array}{r}d o c \mathrm{C} 1 \\
\operatorname{doc} \mathrm{C} 2\end{array}$ & 1835 & $\begin{array}{l}\text { TGAGCTACGCTATCATTG } \\
\text { GCTTACGCTATGGGTTGG }\end{array}$ & Müller et al. [22] \\
\hline & pldA & $\begin{array}{l}\text { pldA-84 } \\
\text { pldA-981 }\end{array}$ & 913 & $\begin{array}{l}\text { AAGCTTATGCGTTTTT } \\
\text { TATAAGGCTTTCTCCA }\end{array}$ & Datta et al. [9] \\
\hline & $c e u \mathrm{E}$ & $\begin{array}{l}\mathrm{JEJ} 1 \\
\mathrm{JEJ} 2\end{array}$ & 794 & $\begin{array}{l}\text { CCTGCTCGGTGAAAGTTTTG } \\
\text { GATCTTTTTGTTTTGTGCTGC }\end{array}$ & Gonzalez et al. [14] \\
\hline & $\mathrm{rac \textrm {R }}$ & $\begin{array}{l}\operatorname{rac} \mathrm{R}-25 \\
\operatorname{rac} \mathrm{R}-593\end{array}$ & 584 & $\begin{array}{l}\text { GATGATCCTGACTTTG } \\
\text { TCTCCTATTTTTACCC }\end{array}$ & Datta et al. [9] \\
\hline & $d n a \mathbf{J}$ & $\begin{array}{c}d n a \mathrm{~J}-299 \\
\text { dnaJ-1003 }\end{array}$ & 720 & $\begin{array}{l}\text { AAGGCTTTGGCTCATC } \\
\text { CTTTTTGTTCATCGTT }\end{array}$ & Datta et al. [9] \\
\hline \multirow{3}{*}{$\begin{array}{l}\text { GBS-associated } \\
\text { genes }\end{array}$} & galE & $\begin{array}{l}\text { galE-F } \\
\text { galE-R }\end{array}$ & 584 & $\begin{array}{l}\text { GATGATCCTGACTTTG } \\
\text { TCTCCTATTTTTACCC }\end{array}$ & Nawaz et al. [23] \\
\hline & $\operatorname{cgt} \mathrm{B}$ & $\begin{array}{c}\text { DL39 } \\
\text { cgtBrev }\end{array}$ & 584 & $\begin{array}{l}\text { GATGATCCTGACTTTG } \\
\text { TCTCCTATTTTTACCC }\end{array}$ & Linton et al. [21] \\
\hline & $w l a \mathrm{~N}$ & $\begin{array}{l}\text { wlaN-DL39 } \\
\text { wlaN-DL41 }\end{array}$ & 584 & $\begin{array}{l}\text { GATGATCCTGACTTTG } \\
\text { TCTCCTATTTTTACCC }\end{array}$ & Linton et al. [21] \\
\hline
\end{tabular}

GBS-associated genes: Guillain-Barré syndrome-associated genes.

then stained with $0.5 \mu \mathrm{g} / \mathrm{mL}$ ethidium bromide.

PCR detections of virulence- and GBS-associated genes PCR was performed as generally same as described in the above CDT case. Primer sets and PCR condition are listed in Table 2.

\section{CDT cytotoxicity assay with HEp-2 cells}

HEp-2 cells were seeded into 24 well tissue culture plates (Nunc, Germany) at a density of $2 \times 10^{4} \mathrm{CFU}$ (colony forming unit) per well in $0.5 \mathrm{~mL}$. Two-fold serial dilutions of culture filtrates were prepared in MEM (Invitrogen, USA) and $0.5 \mathrm{~mL}$ of each dilution was added to the HEp-2 cells and incubated for 3 days at $37^{\circ} \mathrm{C}$ in an atmosphere of $5 \% \mathrm{CO}_{2}$.

Cell-free bacterial culture supernatants from all the strains were prepared according to the method described by Florin and Antillon [12] with minor modifications. Briefly, each strain was harvested from CCDA plates and inoculated into MEM cell culture medium. The volume of medium used was adjusted so that the $\mathrm{OD}_{600}$ of the bacterial suspension was $0.125\left(2 \times 10^{8} \mathrm{CFU} / \mathrm{mL}\right)$. Bacterial strains suspended in MEM tissue culture medium were lysed by sonication $(4 / 30 \mathrm{sec}$ bursts with $30 \mathrm{sec}$ intervals between each burst). Cell debris and intact bacteria were then removed by centrifugation at $3,000 \times \mathrm{g}$ for $20 \mathrm{~min}$ at $5^{\circ} \mathrm{C}$ and sterilized by filteration $(0.22 \mu \mathrm{m})$. Finally, the filtered supernatant was stored at $20^{\circ} \mathrm{C}$ until use. The morphological changes of cells were examined with an aid of inverted microscope at the time of incubation between $24 \mathrm{~h}$ and $72 \mathrm{~h}$.

\section{Adhesion and invasion assay in INT-407 cells}

The adhesion and invasion assays were performed by the method of Konkel et al. [17] with slight modifications. Briefly, C. jejuni strains were grown microaerobically on blood agar with $5 \%$ sheep blood for $48 \mathrm{~h}$ at $37^{\circ} \mathrm{C}$. Bacteria were harvested from the plates with PBS (phosphate buffered saline) and adjusted spectrophotometrically to approximately $1 \times 10^{7} \mathrm{CFU} / \mathrm{mL}$. The CFU containing of approximately 200 times higher than the cell number was inoculated into duplicated wells of a 24 well tissue culture plated containing semiconfluent monolayers of INT-407 cells. The infected monolayers were incubated for $3 \mathrm{~h}$ at $37^{\circ} \mathrm{C}$ in a $5 \% \mathrm{CO}_{2}$ humidified atmosphere to allow for bacterial adherence and internalization. 
For determination of adherence, the cells were washed 3 times with PBS and the cell monolayer was lysed with $1 \%$ Triton X-100 (Sigma, USA) and the total bacteria associated with the cells (intracellular and extracellular bacteria) were enumerated by plating serial dilutions of the lysates on blood agar with 5\% sheep blood. In order to measure bacterial invasion, the infected cells were washed 3 times with PBS and incubated in fresh PBS containing 1\% fetal bovine serum (FBS) and $200 \mu \mathrm{g} / \mathrm{mL}$ gentamicin for $2 \mathrm{~h}$ to kill the remaining viable extracellular bacteria. In preliminary experiments, $200 \mu \mathrm{g} / \mathrm{mL}$ of gentamicin killed all the extracellular bacteria within $2 \mathrm{~h}$ after the exposure. Quantification of viable intracellular bacteria was performed by washing the infected eukaryotic cells twice with PBS and subsequently lysing with $1 \%$ Triton X-100. Following serial dilution in PBS, the released intracellular bacteria were enumerated as described in the adherence assay. Non-invasive $E$. coli DH5 $\alpha$ was used as negative control for all the analyses. The correlation between the adherence to and invasion of the INT-407 cells for Campylobacter spp. isolates was analyzed by a linear regression using SPSS (SPSS, USA).

\section{Results}

\section{Prevalence of thermophilic Campylobacter spp.}

The isolates of Campylobacter spp. were identified by using Multi-perfect Campylobacter spp. PCR kit. The mPCR could amplify $800 \mathrm{bp}$ band for Campylobacter spp., $502 \mathrm{bp}$ band for C. coli, $251 \mathrm{bp}$ band for $C$. lari, $161 \mathrm{bp}$ band for $C$. jejuni, and $86 \mathrm{bp}$ band for C. upsaliensis (Fig. 1). A total of 44 strains of $C$. jejuni, 9 strains of $C$. coli, 6 strains of $C$. upsaliensis and 1 strain of $C$. lari were isolated from dogs in Gyeongnam and Busan areas (Table 3). The rates of isolation for the thermophilic Campylobacter spp. were 8.8\% (24/ $274)$ in household dogs, $12.0 \%(10 / 83)$ in breeding dogs, and $25.2 \%(26 / 103)$ in the stray dogs. In the fecal samples of household dogs, the isolation rate for $C$. jejuni was $54.2 \%$ (13/24), C. upsaliensis $25.0 \%$ (6/24), C. coli $16.7 \%(4 / 24)$ and C. lari $4.2 \%(1 / 24)$. In the fecal samples of stray dogs, the isolation rate for $C$. jejuni was $88.5 \%(23 / 26)$ and for $C$. coli was $11.5 \%(3 / 23)$. In the fecal samples of the breeding dogs, the isolation rate for $C$. jejuni was $80.0 \%(8 / 10)$ and for $C$. coli was $20.0 \%(2 / 10)$. C. upsaliensis and $C$. lari were not isolated in the stray and breeding dogs.

\section{CDT gene detection and cytotoxicity assay}

The prevalence of CDT genes was detected by MPCR with 87 C. jejuni and 13 C. coli strains isolated from dogs and humans. The $c d t \mathrm{~A}, c d t \mathrm{~B}$ and $c d t \mathrm{C}$ genes were detected in the all isolates (Table 4). Cytotoxicity assay was performed by microscopic examination of HEp-2 cells treated with the prepared culture supernatants to observe formation of small polymorphic, rounded cells, and elongated cells with irregular vacuoles formation in the peri-nuclear cytoplasm, those are associated with CDT activity. As a result, a total of 27

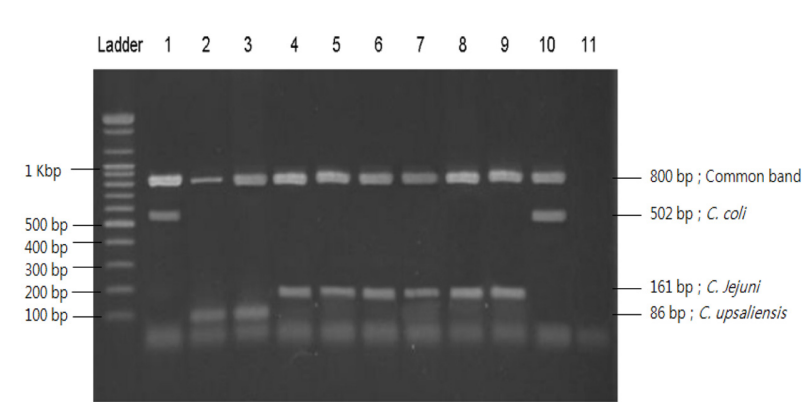

Fig. 1. Identification of thermophilic Campylobacter $(C$.) spp. by multiplex polymerase chain reaction (m-PCR). Ladder; 100 bp marker, Lane 1; C. coli (ATCC 33559), Lane 2; C. upsalienesis (ATCC 43954), Lane 3; C. upsalienesis (isolate), Lane 4; C. jejuni (ATCC 33560), Lane 5 9; C. jejuni (isolates), Lane 10; C. coli (isolate).

strains of Campylobacter spp. displayed cytotoxicity, among them, $26(31.0 \%)$ of $C$. jejuni and 1 (15.3\%) of the C. coli isolates showed evidence for CDT production in the HEp-2 cell cytotoxicity assays (Table 5). Among the 26 C. jejuni isolates that were positive to cytotoxicity assay, 15 strains were human origin, and the remaining was dogs origin isolates. Only one isolate of $C$. coli isolated from dog showed a cytotoxicity of HEp-2 cells.

\section{Detection of virulence-associated genes}

Thirteen virulence-associated genes were detected in 87 strains of $C$. jejuni and 13 strains of $C$. coli isolates from humans and dogs by using mPCR method. Four virulenceassociated genes $(c a d \mathrm{~F}, d n a \mathrm{~J}, f l a \mathrm{~A}$, and $c e u \mathrm{E})$ were detected in the all isolates of $C$. jejuni and $C$. coli from dogs and humans (Table 6). The racR gene was detected as $90 \sim 100 \%$ in $C$. jejuni isolated from dogs and humans, and in C. coli from humans, however, it was not detected in $C$. coli isolated from dogs. The $c i a \mathrm{~B}$ gene was detected as $40 \sim 87.5 \%$ in C. jejuni isolated from dogs and humans, and in C. coli from humans, however it was not detected in $C$. coli isolated from dogs. The iamA gene was detected as $80-100 \%$ in $C$. jejuni isolated from dogs and humans, and $50 \%$ in $C$. coli isolated from dogs, however it was not detected in $C$. coli isolated from dogs. The pldA gene was detected as $40 \sim 90 \%$ in $C$. jejuni isolated from dogs and humans, and in $C$. coli isolated from humans, however it was not detected in $C$. coli isolated from dogs. The virB11 was detected as only $6.5 \%$ in $\mathrm{C}$. jejuni isolated from humans. The $d o c \mathrm{C}$ was detected as $19.5 \sim 82.0 \%$ in C. jejuni isolated from dogs and humans, however, it was not detected in $C$. coli isolates.

\section{Detection of GBS-associated genes}

Three GBS-associated genes $($ gal $\mathrm{E}, \operatorname{cgt} \mathrm{B}$, wla $\mathrm{N})$ were detected by mPCR method. These 3 GBS-associated genes were detected in total 87 strains of $C$. jejuni and 13 strains of C. coli isolates from humans and dogs. The galE gene was detected in all C. jejuni and $C$. coli isolated from dogs and 
Table 3. The isolation rates of thermophilic Campylobacter spp. isolated from dogs faeces in Gyeongnam and Busan areas

\begin{tabular}{|c|c|c|c|c|}
\hline Species & $\begin{array}{l}\text { Household dogs } \\
\quad(\mathrm{n}=274)\end{array}$ & $\begin{array}{c}\text { Stray dogs } \\
(\mathrm{n}=103)\end{array}$ & $\begin{array}{l}\text { Breeding dogs } \\
\quad(\mathrm{n}=83)\end{array}$ & $\begin{array}{c}\text { Total } \\
(\mathrm{n}=460)\end{array}$ \\
\hline & $\mathrm{n}(\%)$ & n $(\%)$ & n $(\%)$ & n $(\%)$ \\
\hline C. jejuni & $13(54.2)$ & $23(88.5)$ & $8(80.0)$ & 44 \\
\hline C. coli & $4(16.7)$ & $3(11.5)$ & $2(20.0)$ & 9 \\
\hline C. upsaliensis & $6(25.0)$ & - & - & 6 \\
\hline C. lari & $1(4.2)$ & - & - & 1 \\
\hline Total & $24(8.8)$ & $26(25.2)$ & $10(12.0)$ & $60(13.2)$ \\
\hline
\end{tabular}

Table 4. Detection rate of CDT genes from C. jejuni and C. coli isolates

\begin{tabular}{|c|c|c|c|c|c|c|c|c|}
\hline & \multicolumn{6}{|c|}{ Origin } & & \\
\hline & \multicolumn{2}{|c|}{ Household Dogs } & \multicolumn{2}{|c|}{ Stray dogs } & \multicolumn{2}{|c|}{ Breading Dogs } & \multicolumn{2}{|c|}{ Humans } \\
\hline & $\begin{array}{c}\text { C. jejuni } \\
(\%)\end{array}$ & $\begin{array}{l}\text { C. coli } \\
(\%)\end{array}$ & $\begin{array}{c}\text { C. jejuni } \\
(\%)\end{array}$ & $\begin{array}{l}\text { C. coli } \\
(\%)\end{array}$ & $\begin{array}{c}\text { C. jejuni } \\
(\%)\end{array}$ & $\begin{array}{l}\text { C. coli } \\
(\%)\end{array}$ & $\begin{array}{c}\text { C. jejuni } \\
(\%)\end{array}$ & $\begin{array}{l}\text { C. coli } \\
(\%)\end{array}$ \\
\hline$c d t \mathrm{~A}$ & $\begin{array}{l}10 / 10 \\
(100)\end{array}$ & $\begin{array}{c}4 / 4 \\
(100)\end{array}$ & $\begin{array}{c}23 / 23 \\
(100)\end{array}$ & $\begin{array}{c}3 / 3 \\
(100)\end{array}$ & $\begin{array}{c}8 / 8 \\
(100)\end{array}$ & $\begin{array}{c}2 / 2 \\
(100)\end{array}$ & $\begin{array}{l}46 / 46 \\
(100)\end{array}$ & $\begin{array}{c}4 / 4 \\
(100)\end{array}$ \\
\hline$c d t \mathrm{~B}$ & $\begin{array}{l}10 / 10 \\
(100)\end{array}$ & $\begin{array}{l}4 / 4 \\
(100)\end{array}$ & $\begin{array}{c}23 / 23 \\
(100)\end{array}$ & $\begin{array}{l}3 / 3 \\
(100)\end{array}$ & $\begin{array}{l}8 / 8 \\
(100)\end{array}$ & $\begin{array}{l}2 / 2 \\
(100)\end{array}$ & $\begin{array}{r}46 / 46 \\
(100)\end{array}$ & $\begin{array}{c}4 / 4 \\
(100)\end{array}$ \\
\hline$c d t \mathrm{C}$ & $\begin{array}{l}10 / 10 \\
(100)\end{array}$ & $\begin{array}{l}4 / 4 \\
(100)\end{array}$ & $\begin{array}{c}23 / 23 \\
(100)\end{array}$ & $\begin{array}{l}3 / 3 \\
(100)\end{array}$ & $\begin{array}{l}8 / 8 \\
(100)\end{array}$ & $\begin{array}{l}2 / 2 \\
(100)\end{array}$ & $\begin{array}{r}46 / 46 \\
(100)\end{array}$ & $\begin{array}{c}4 / 4 \\
(100)\end{array}$ \\
\hline
\end{tabular}

Table 5. Determination of cytotoxic activity from C. jejuni and C. coli isolates

\begin{tabular}{cccc}
\hline \hline & & Origin & \multirow{2}{*}{ Total (\%) } \\
\cline { 2 - 3 } & Dogs $(\%)$ & Humans $(\%)$ & $26 / 87(31.0)$ \\
C. jejuni & $11 / 41(26.8)$ & $15 / 46(32.6)$ & $1 / 13(15.3)$ \\
C. coli & $1 / 9(11.1)$ & $0 / 4(0)$ & $27 / 100(27.0)$ \\
\hline
\end{tabular}

Table 6. Isolation rates of virulence-associated genes in $C$. jejuni and $C$. coli isolates from dogs and humans

\begin{tabular}{|c|c|c|c|c|c|c|c|c|}
\hline \multirow[b]{2}{*}{ Gene } & \multicolumn{2}{|c|}{ Household Dogs } & \multicolumn{2}{|c|}{ Stray Dogs } & \multicolumn{2}{|c|}{ Breading Dogs } & \multicolumn{2}{|c|}{ Humans } \\
\hline & $\begin{array}{c}\text { C. jejuni } \\
(\%)\end{array}$ & $\begin{array}{c}\text { C. coli } \\
(\%)\end{array}$ & $\begin{array}{c}\text { C. jejuni } \\
(\%)\end{array}$ & $\begin{array}{c}\text { C. coli } \\
(\%)\end{array}$ & $\begin{array}{c}\text { C. jejuni } \\
(\%)\end{array}$ & $\begin{array}{l}\text { C. coli } \\
(\%)\end{array}$ & $\begin{array}{c}\text { C. jejuni } \\
(\%)\end{array}$ & $\begin{array}{c}\text { C. coli } \\
(\%)\end{array}$ \\
\hline$c a d \mathrm{~F}$ & $\begin{array}{l}10 / 10 \\
(100)\end{array}$ & $\begin{array}{c}/ 4 \\
(100)\end{array}$ & $\begin{array}{l}23 / 23 \\
(100)\end{array}$ & $\begin{array}{c}3 / 3 \\
(100)\end{array}$ & $\begin{array}{c}8 / 8 \\
(100)\end{array}$ & $\begin{array}{c}2 / 2 \\
(100)\end{array}$ & $\begin{array}{l}46 / 46 \\
(100)\end{array}$ & $\begin{array}{c}4 / 4 \\
(100)\end{array}$ \\
\hline$d n a \mathrm{~J}$ & $\begin{array}{l}10 / 10 \\
(100)\end{array}$ & $\begin{array}{c}4 / 4 \\
(100)\end{array}$ & $\begin{array}{c}23 / 23 \\
(100)\end{array}$ & $\begin{array}{c}3 / 3 \\
(100)\end{array}$ & $\begin{array}{c}8 / 8 \\
(100)\end{array}$ & $\begin{array}{c}2 / 2 \\
(100)\end{array}$ & $\begin{array}{c}46 / 46 \\
(100)\end{array}$ & $\begin{array}{c}4 / 4 \\
(100)\end{array}$ \\
\hline flaA & $\begin{array}{c}10 / 10 \\
(100)\end{array}$ & $\begin{array}{c}4 / 4 \\
(100)\end{array}$ & $\begin{array}{l}23 / 23 \\
(100)\end{array}$ & $\begin{array}{c}3 / 3 \\
(100)\end{array}$ & $\begin{array}{c}8 / 8 \\
(100)\end{array}$ & $\begin{array}{c}2 / 2 \\
(100)\end{array}$ & $\begin{array}{l}46 / 46 \\
(100)\end{array}$ & $\begin{array}{c}4 / 4 \\
(100)\end{array}$ \\
\hline$c e u \mathrm{E}$ & $\begin{array}{c}10 / 10 \\
(100)\end{array}$ & $\begin{array}{c}4 / 4 \\
(100)\end{array}$ & $\begin{array}{c}23 / 23 \\
(100)\end{array}$ & $\begin{array}{c}3 / 3 \\
(100)\end{array}$ & $\begin{array}{c}8 / 8 \\
(100)\end{array}$ & $\begin{array}{c}2 / 2 \\
(100)\end{array}$ & $\begin{array}{r}46 / 46 \\
(100)\end{array}$ & $\begin{array}{c}4 / 4 \\
(100)\end{array}$ \\
\hline $\operatorname{rac} \mathrm{R}$ & $\begin{array}{l}9 / 10 \\
(90)\end{array}$ & $\begin{array}{l}0 / 4 \\
(0)\end{array}$ & $\begin{array}{l}23 / 23 \\
(100)\end{array}$ & $\begin{array}{l}0 / 3 \\
(0)\end{array}$ & $\begin{array}{c}8 / 8 \\
(100)\end{array}$ & $\begin{array}{l}0 / 2 \\
(0)\end{array}$ & $\begin{array}{l}45 / 46 \\
(97.8)\end{array}$ & $\begin{array}{c}4 / 4 \\
(100)\end{array}$ \\
\hline$c i a \mathrm{~B}$ & $\begin{array}{l}4 / 10 \\
(40)\end{array}$ & $\begin{array}{l}0 / 4 \\
(0)\end{array}$ & $\begin{array}{l}19 / 23 \\
(82.6)\end{array}$ & $\begin{array}{l}0 / 3 \\
(0)\end{array}$ & $\begin{array}{c}7 / 8 \\
(87.5)\end{array}$ & $\begin{array}{l}0 / 2 \\
(0)\end{array}$ & $\begin{array}{l}30 / 46 \\
(65.2)\end{array}$ & $\begin{array}{c}2 / 4 \\
(50)\end{array}$ \\
\hline $\operatorname{iam} \mathrm{A}$ & $\begin{array}{l}8 / 10 \\
(80)\end{array}$ & $\begin{array}{l}0 / 4 \\
(0)\end{array}$ & $\begin{array}{l}23 / 23 \\
(100)\end{array}$ & $\begin{array}{l}0 / 3 \\
(0)\end{array}$ & $\begin{array}{c}8 / 8 \\
(100)\end{array}$ & $\begin{array}{c}1 / 2 \\
(50)\end{array}$ & $\begin{array}{l}46 / 46 \\
(100)\end{array}$ & $\begin{array}{c}4 / 4 \\
(100)\end{array}$ \\
\hline pldA & $\begin{array}{l}4 / 10 \\
(40)\end{array}$ & $\begin{array}{l}0 / 4 \\
(0)\end{array}$ & $\begin{array}{l}22 / 23 \\
(95.7)\end{array}$ & $\begin{array}{l}0 / 3 \\
(0)\end{array}$ & $\begin{array}{c}6 / 8 \\
(75)\end{array}$ & $\begin{array}{l}0 / 2 \\
(0)\end{array}$ & $\begin{array}{l}28 / 46 \\
(60.9)\end{array}$ & $\begin{array}{c}2 / 4 \\
(50)\end{array}$ \\
\hline $\operatorname{virB} 11$ & $\begin{array}{l}0 / 10 \\
(0)\end{array}$ & $\begin{array}{l}0 / 4 \\
(0)\end{array}$ & $\begin{array}{c}0 / 23 \\
(0)\end{array}$ & $\begin{array}{l}0 / 3 \\
(0)\end{array}$ & $\begin{array}{l}0 / 8 \\
(0)\end{array}$ & $\begin{array}{l}0 / 2 \\
(0)\end{array}$ & $\begin{array}{l}3 / 46 \\
(6.5)\end{array}$ & $\begin{array}{l}0 / 4 \\
(0)\end{array}$ \\
\hline$d o c \mathrm{C}$ & $\begin{array}{l}7 / 10 \\
(70)\end{array}$ & $\begin{array}{l}0 / 4 \\
(0)\end{array}$ & $\begin{array}{l}19 / 23 \\
(82.6)\end{array}$ & $\begin{array}{l}0 / 3 \\
(0)\end{array}$ & $\begin{array}{c}3 / 8 \\
(37.5)\end{array}$ & $\begin{array}{l}0 / 2 \\
(0)\end{array}$ & $\begin{array}{l}9 / 46 \\
(19.6)\end{array}$ & $\begin{array}{l}0 / 4 \\
(0)\end{array}$ \\
\hline
\end{tabular}


Table 7. Isolation rates of GBS genes in C. jejuni and C. coli isolates from dogs and humans

\begin{tabular}{ccccc}
\hline \hline \multirow{2}{*}{ Gene } & \multicolumn{3}{c}{ Dogs } & Humans \\
\cline { 2 - 5 } & C. jejuni $(\%)$ & C. coli $(\%)$ & C. jejuni $(\%)$ & C. coli $(\%)$ \\
\hline cgtB & $10 / 41(24.4)$ & $0 / 9(0)$ & $33 / 46(71.7)$ & $3 / 4(75.0)$ \\
galE & $41 / 41(100)$ & $9 / 9(100)$ & $46 / 46(100)$ & $4 / 4(100)$ \\
wla $\mathrm{N}$ & $0 / 41(0)$ & $0 / 9(0)$ & $8 / 46(17.4)$ & $2 / 4(50.0)$ \\
\hline
\end{tabular}

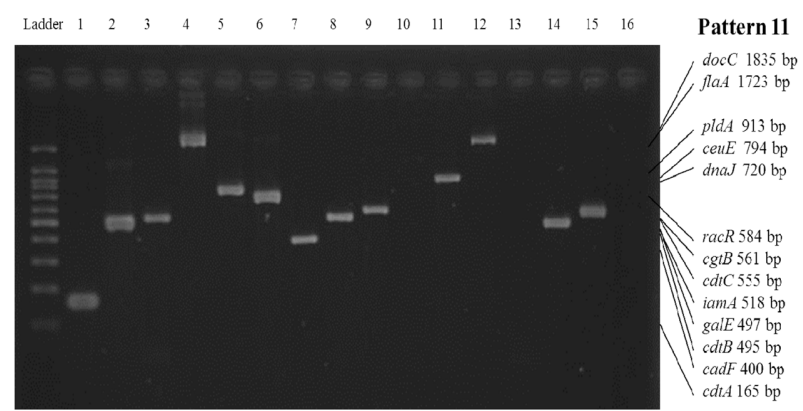

Fig. 2. Representative pattern of PCR amplifications for virulence-associated genes in C. jejuni D16, 17, 23 and 41 isolated from dogs. Ladder; $100 \mathrm{bp}$ marker.

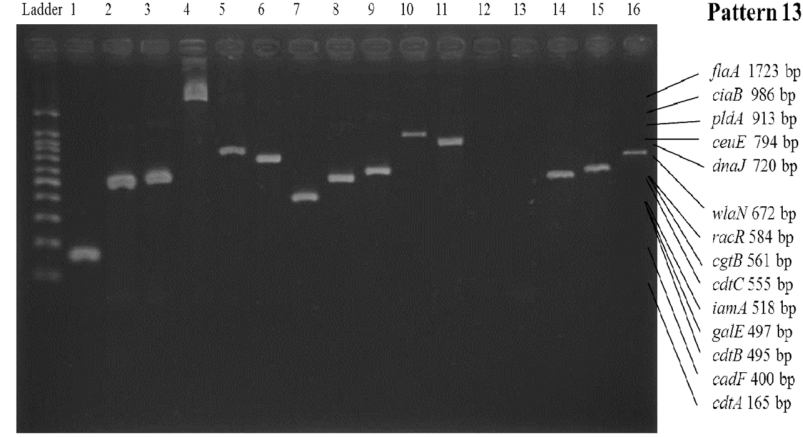

Fig. 3. Representative pattern of PCR amplifications for virulence-associated genes in C. jejuni $\mathrm{H} 19,28$ and $C$. coli $\mathrm{H} 24$ isolated from humans. Ladder; $100 \mathrm{bp}$ marker.

Table 8. Virulence-associated gene patterns of $C$. jejuni and $C$. coli isolated from dogs

\begin{tabular}{|c|c|c|c|}
\hline Number & Patterns & C. jejuni & C. coli \\
\hline 1 & $c d t \mathrm{~A}, c d t \mathrm{~B}, c d t \mathrm{C}, c a d \mathrm{~F}, c e u \mathrm{E}, d n a \mathrm{~J}, f l a \mathrm{~A}, g a l \mathrm{E}$ & 8 & 8 \\
\hline 2 & $c d t \mathrm{~A}, c d t \mathrm{~B}, c d t \mathrm{C}, c a d \mathrm{~F}, c e u \mathrm{E}, d n a \mathrm{~J}, \operatorname{fla} \mathrm{A}, \operatorname{gal} \mathrm{E}, \operatorname{iam} \mathrm{A}$ & 1 & 1 \\
\hline 3 & $c d t \mathrm{~A}, c d t \mathrm{~B}, c d t \mathrm{C}, c a d \mathrm{~F}, c e u \mathrm{E}, d n a \mathrm{~J}, \operatorname{fla} \mathrm{A}, \operatorname{gal} \mathrm{E}, \operatorname{iam} \mathrm{A}, \operatorname{rac} \mathrm{R}$ & 3 & \\
\hline 4 & $c d t \mathrm{~A}, c d t \mathrm{~B}, c d t \mathrm{C}, c a d \mathrm{~F}, c e u \mathrm{E}, c i a \mathrm{~B}, d n a \mathrm{~J}, \operatorname{fla} \mathrm{A}, \operatorname{gal} \mathrm{E}, \operatorname{iam} \mathrm{A}, \operatorname{rar} \mathrm{R}$ & 2 & \\
\hline 5 & $c d t \mathrm{~A}, c d t \mathrm{~B}, c d t \mathrm{C}, c a d \mathrm{~F}, c e u \mathrm{E}, c g t \mathrm{~B}, d n a \mathrm{~J}, d o c \mathrm{C}, \operatorname{fla} \mathrm{A}, g a l \mathrm{E}, \operatorname{iam} \mathrm{A}, r a c \mathrm{R}$ & 1 & \\
\hline 6 & $c d t \mathrm{~A}, c d t \mathrm{~B}, c d t \mathrm{C}, c a d \mathrm{~F}, c e u \mathrm{E}, c g t \mathrm{~B}, d n a \mathrm{~J}, \operatorname{fla} \mathrm{A}, g a l \mathrm{E}, \operatorname{cam} \mathrm{A}, p l d \mathrm{~A}, r a c \mathrm{R}$ & 1 & \\
\hline 7 & $c d t \mathrm{~A}, c d t \mathrm{~B}, c d t \mathrm{C}, c a d \mathrm{~F}, c e u \mathrm{E}, c i a \mathrm{~B}, d n a \mathrm{~J}, d o c \mathrm{C}, f l a \mathrm{~A}, \operatorname{gal} \mathrm{E}, i a m \mathrm{~A}, r a c \mathrm{R}$ & 2 & \\
\hline 8 & $c d t \mathrm{~A}, c d t \mathrm{~B}, c d t \mathrm{C}, c a d \mathrm{~F}, c e u \mathrm{E}, c i a \mathrm{~B}, d n a \mathrm{~J}, \operatorname{fla} \mathrm{A}, \operatorname{gal} \mathrm{E}, i a m \mathrm{~A}, p l d \mathrm{~A}, r a c \mathrm{R}$ & 2 & \\
\hline 9 & $c d t \mathrm{~A}, c d t \mathrm{~B}, c d t \mathrm{C}, c a d \mathrm{~F}, c e u \mathrm{E}, d n a \mathrm{~J}, d o c \mathrm{C}, \operatorname{fla} \mathrm{A}, g a l \mathrm{E}, \operatorname{iam} \mathrm{A}, p l d \mathrm{~A}, \operatorname{rac} \mathrm{R}$ & 1 & \\
\hline 10 & $c d t \mathrm{~A}, c d t \mathrm{~B}, c d t \mathrm{C}, c a d \mathrm{~F}, c e u \mathrm{E}, c g t \mathrm{~B}, c i a \mathrm{~B}, d n a \mathrm{~J}, \operatorname{fla} \mathrm{A}, \operatorname{gal} \mathrm{E}, \operatorname{iam} \mathrm{A}, p l d \mathrm{~A}, \operatorname{rac} \mathrm{R}$ & 3 & \\
\hline 11 & $c d t \mathrm{~A}, c d t \mathrm{~B}, c d t \mathrm{C}, c a d \mathrm{~F}, c e u \mathrm{E}, c g t \mathrm{~B}, d n a \mathrm{~J}, d o c \mathrm{C}, \operatorname{fla} \mathrm{A}, g a l \mathrm{E}, \operatorname{cam} \mathrm{A}, p l d \mathrm{~A}, \operatorname{rac} \mathrm{R}$ & 4 & \\
\hline 12 & $c d t \mathrm{~A}, c d t \mathrm{~B}, c d t \mathrm{C}, c a d \mathrm{~F}, c e u \mathrm{E}, c i a \mathrm{~B}, d n a \mathrm{~J}, d o c \mathrm{C}, \operatorname{fla} \mathrm{A}, \operatorname{gal} \mathrm{E}, i a m \mathrm{~A}, p l d \mathrm{~A}, \operatorname{rac} \mathrm{R}$ & 20 & \\
\hline \multirow[t]{2}{*}{13} & $c d t \mathrm{~A}, c d t \mathrm{~B}, c d t \mathrm{C}, c a d \mathrm{~F}, c e u \mathrm{E}, c g t \mathrm{~B}, c i a \mathrm{~B}, d n a \mathrm{~J}, d o c \mathrm{C}, \operatorname{fla} \mathrm{A}, g a l \mathrm{E}, \operatorname{iam} \mathrm{A}, p l d \mathrm{~A}, \operatorname{rac} \mathrm{R}$ & 1 & \\
\hline & Total & 41 & 9 \\
\hline
\end{tabular}

humans. The $c g t \mathrm{~B}$ gene was detected as $24.4 \%$ in $C$. jejuni isolated from dogs, $71.7 \%$ in $C$. jejuni, and $75.0 \%$ in $C$. coli isolated from humans, however, it was not detected in C. coli isolated from dogs (Table 7). The wlaN gene was not detected in Campylobacter spp. isolated from dogs, however the detection rates were 17.4 and $50.0 \%$ in C. jejuni and $C$. coli isolated from humans, respectively.

\section{Occurrence pattern of virulence-associated genes in Campylobacter spp. isolates}

Patterns of virulence-associated genes of Campylobacter isolates from humans and dogs were compared with 16 kinds of genes. Compared with the gene occurrence pattern among the $41 C$. jejuni isolates from dogs, 13-gene occurrence pattern was detected in 27 strains, 8-gene occurrence pattern was detected in 8 strains, 12-gene occurrence pattern was detected in 7 strains (Table 8 and Fig. 2). However, in the gene occurrence patterns of $46 C$. jejuni isolates from humans, 12-gene pattern was for 13 strains, 11-gene pattern was for 12 strains, 14-gene pattern was for 11 strains, 13-gene pattern was for 6 strains, and 10-gene pattern was for 3 strains (Table 9 and Fig. 3).

When compared the gene harboring patterns of 9 C. coli isolates from dogs, 8-gene pattern was occurred in 8 strains, 
Table 9. Virulence-associated gene patterns of $C$. jejuni and C. coli isolated from humans

\begin{tabular}{|c|c|c|c|}
\hline Number & Patterns & C. jejuni & C. coll \\
\hline 1 & $c d t \mathrm{~A}, c d t \mathrm{~B}, c d t \mathrm{C}, c a d \mathrm{~F}, c e u \mathrm{E}, d n a \mathrm{~J}, f l a \mathrm{~A}, \operatorname{gal} \mathrm{E}, \operatorname{iam} \mathrm{A}, \operatorname{rac} \mathrm{R}$ & 3 & \\
\hline 2 & $c d t \mathrm{~A}, c d t \mathrm{~B}, c d t \mathrm{C}, c a d \mathrm{~F}, c e u \mathrm{E}, c g t \mathrm{~B}, d n a \mathrm{~J}, \operatorname{fla} \mathrm{A}, g a l \mathrm{E}, \operatorname{ram} \mathrm{A}, r a c \mathrm{R}$ & 12 & 2 \\
\hline 3 & $c d t \mathrm{~A}, c d t \mathrm{~B}, c d t \mathrm{C}, c a d \mathrm{~F}, c e u \mathrm{E}, c g t \mathrm{~B}, d n a \mathrm{~J}, \operatorname{fla} \mathrm{A}, g a l \mathrm{E}, \operatorname{iam} \mathrm{A}, p l d \mathrm{~A}, r a c \mathrm{R}$ & 2 & \\
\hline 4 & $c d t \mathrm{~A}, c d t \mathrm{~B}, c d t \mathrm{C}, c a d \mathrm{~F}, c e u \mathrm{E}, c g t \mathrm{~B}, c i a \mathrm{~B}, d n a \mathrm{~J}, \operatorname{fla} \mathrm{A}, \operatorname{gal} \mathrm{E}, i a m \mathrm{~A}, \operatorname{rac} \mathrm{R}$ & 5 & \\
\hline 5 & $c d t \mathrm{~A}, c d t \mathrm{~B}, c d t \mathrm{C}, c a d \mathrm{~F}, c e u \mathrm{E}, c g t \mathrm{~B}, d n a \mathrm{~J}, \operatorname{fla} \mathrm{A}, g a l \mathrm{E}, \operatorname{iam} \mathrm{A}, r a c \mathrm{R}, w l a \mathrm{~N}$ & 1 & \\
\hline 6 & $c d t \mathrm{~A}, c d t \mathrm{~B}, c d t \mathrm{C}, c a d \mathrm{~F}, c e u \mathrm{E}, c i a \mathrm{~B}, d n a \mathrm{~J}, \operatorname{fla} \mathrm{A}, \operatorname{gal} \mathrm{E}, \operatorname{iam} \mathrm{A}, p l d \mathrm{~A}, r a c \mathrm{R}$ & 3 & \\
\hline 7 & $c d t \mathrm{~A}, c d t \mathrm{~B}, c d t C, c a d \mathrm{~F}, c e u \mathrm{E}, d n a \mathrm{~J}, d o c \mathrm{C}, f l a \mathrm{~A}, \operatorname{gal} \mathrm{E}, i a m \mathrm{~A}, p l d \mathrm{~A}, r a c \mathrm{R}$ & 2 & \\
\hline 8 & $c d t \mathrm{~A}, c d t \mathrm{~B}, c d t \mathrm{C}, c a d \mathrm{~F}, c e u \mathrm{E}, c i a \mathrm{~B}, d n a \mathrm{~J}, d o c \mathrm{C}, \operatorname{fla} \mathrm{A}, \operatorname{gal} \mathrm{E}, \operatorname{iam} \mathrm{A}, \operatorname{pld} \mathrm{A}, \operatorname{rac} \mathrm{R}$ & 3 & \\
\hline 9 & $c d t \mathrm{~A}, c d t \mathrm{~B}, c d t \mathrm{C}, c a d \mathrm{~F}, c e u \mathrm{E}, c g t \mathrm{~B}, c i a \mathrm{~B}, d n a \mathrm{~J}, \operatorname{fla} \mathrm{A}, g a l \mathrm{E}, i a m \mathrm{~A}, p l d \mathrm{~A}, \operatorname{rac} \mathrm{R}$ & 1 & \\
\hline 10 & $c d t \mathrm{~A}, c d t \mathrm{~B}, c d t \mathrm{C}, c a d \mathrm{~F}, c e u \mathrm{E}, c i a \mathrm{~B}, d n a \mathrm{~J}, \operatorname{fla} \mathrm{A}, \operatorname{gal} \mathrm{E}, i a m \mathrm{~A}, p l d \mathrm{~A}, r a c \mathrm{R}, w l a \mathrm{~N}$ & 2 & 1 \\
\hline 11 & $c d t \mathrm{~A}, c d t \mathrm{~B}, c d t \mathrm{C}, c a d \mathrm{~F}, c e u \mathrm{E}, c g t \mathrm{~B}, c i a \mathrm{~B}, d n a \mathrm{~J}, d o c \mathrm{C}, \operatorname{fla} \mathrm{A}, \operatorname{gal} \mathrm{E}, \operatorname{iam} \mathrm{A}, p l d \mathrm{~A}, \operatorname{rac} \mathrm{R}$ & 4 & \\
\hline 12 & $c d t \mathrm{~A}, c d t \mathrm{~B}, c d t \mathrm{C}, c a d \mathrm{~F}, c e u \mathrm{E}, c g t \mathrm{~B}, c i a \mathrm{~B}, d n a \mathrm{~J}, f l a \mathrm{~A}, g a l \mathrm{E}, i a m \mathrm{~A}, p l d \mathrm{~A}, r a c \mathrm{R}, v i r \mathrm{~B}$ & 2 & \\
\hline 13 & $c d t \mathrm{~A}, c d t \mathrm{~B}, c d t \mathrm{C}, c a d \mathrm{~F}, c e u \mathrm{E}, c g t \mathrm{~B}, c i a \mathrm{~B}, d n a \mathrm{~J}, \operatorname{fla} \mathrm{A}, \operatorname{gal} \mathrm{E}, \operatorname{iam} \mathrm{A}, p l d \mathrm{~A}, r a c \mathrm{R}, w l a \mathrm{~N}$ & 2 & 1 \\
\hline 14 & $c d t \mathrm{~A}, c d t \mathrm{~B}, c d t \mathrm{C}, c a d \mathrm{~F}, c e u \mathrm{E}, c g t \mathrm{~B}, d n a \mathrm{~J}, d o c \mathrm{C}, \operatorname{fla} \mathrm{A}, g a l \mathrm{E}, \operatorname{ram} \mathrm{A}, p l d \mathrm{~A}, r a c \mathrm{R}, w l a \mathrm{~N}$ & 1 & \\
\hline 15 & $c d t \mathrm{~A}, c d t \mathrm{~B}, c d t \mathrm{C}, c a d \mathrm{~F}, c e u \mathrm{E}, c g t \mathrm{~B}, d n a \mathrm{~J}, \operatorname{fla} \mathrm{A}, g a l \mathrm{E}, \operatorname{ram} \mathrm{A}, p l d \mathrm{~A}, \operatorname{rac} \mathrm{R}, v i r \mathrm{~B}, w l a \mathrm{~N}$ & 1 & \\
\hline \multirow[t]{2}{*}{16} & $c d t \mathrm{~A}, c d t \mathrm{~B}, c d t \mathrm{C}, c a d \mathrm{~F}, c e u \mathrm{E}, c i a \mathrm{~B}, d n a \mathrm{~J}, d o c \mathrm{C}, \operatorname{fla} \mathrm{A}, g a l \mathrm{E}, \operatorname{iam} \mathrm{A}, p l d \mathrm{~A}, \operatorname{rac} \mathrm{R}, w l a \mathrm{~N}$ & 1 & \\
\hline & Total & 46 & 4 \\
\hline
\end{tabular}

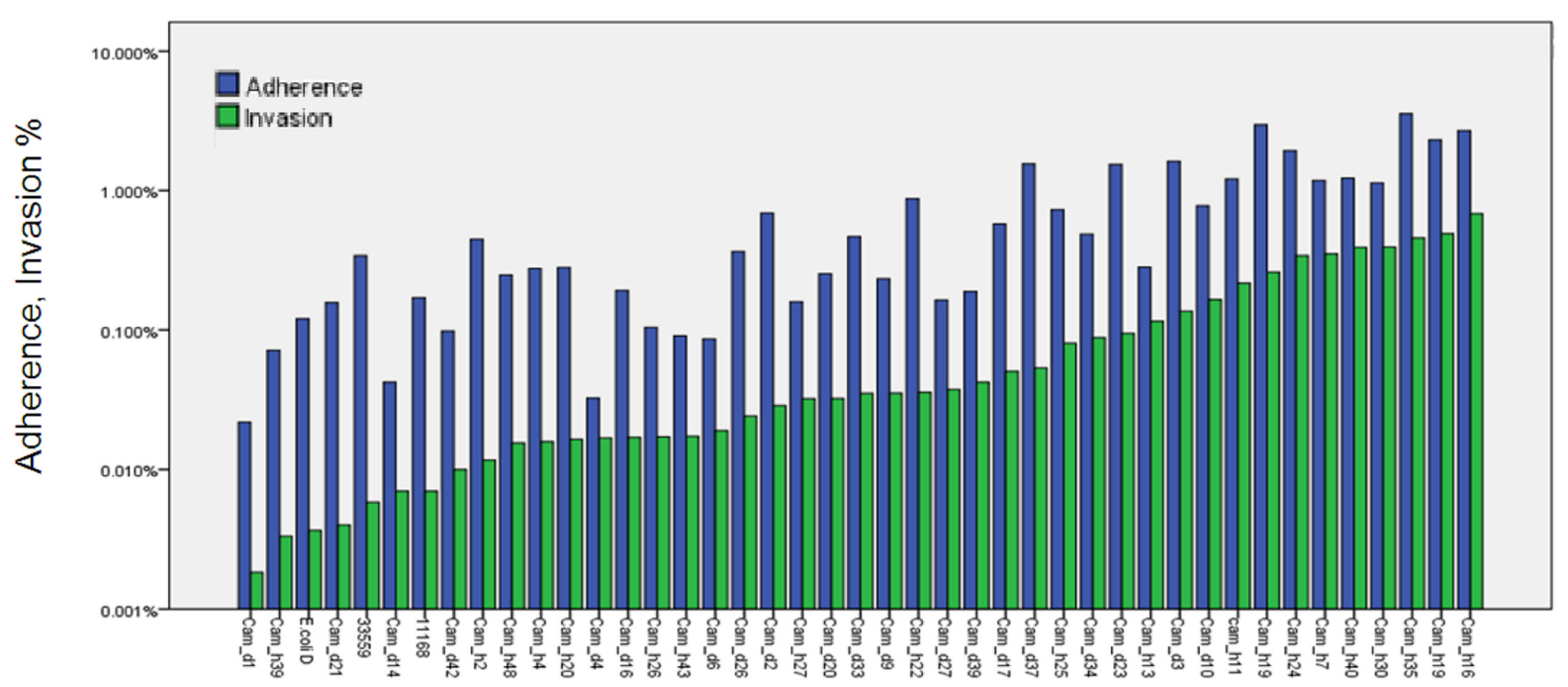

Fig 4. The adherence and invasion ability of $C$. jejuni and $C$. coli into INT-407 cells. There was a significant correlation $\left(R^{2}=0.678\right)$ between the adherence and invasion ability. Cam_h; human isolates, Cam_d; dog isolates, E.coli D; Escherichia coli DH5 $\alpha$.

9-gene pattern was occurred in 1 strain (Table 8). However, in the gene occurrence patterns of 4 C. coli isolates from humans, 11-gene pattern was for 2 strains, 13-gene and 14gene pattern was for 1 strain, respectively (Table 9).

\section{Adherence and invasion assays}

To test the pathogenic properties of $C$. jejuni and C. coli isolates, the adherence and invasion abilities of 40 C. jejuni and $C$. coli isolates from dogs and humans were analyzed with human embryonic intestine (INT-407) cells using a gentamicin resistance assay. After $3 \mathrm{~h}$ incubation, the $40 \mathrm{C}$. jejuni and $C$. coli isolates adhered to INT-407 cells between $8.5 \pm 6.0 \times 10^{3} \mathrm{CFU} / \mathrm{mL}$ and $7.098 \pm 6.025 \times 10^{5} \mathrm{CFU} / \mathrm{mL}$, respectively, and that could be expressed as $0.0180 \%$ to $2.6822 \%$ adherence of the starting viable inoculum. Two of 40 isolates had invasion abilities lower than that of $E$. coli DH5 $\alpha$. The invasion abilities of the 40 isolates to INT-407 were between $3.67 \pm 2.89 \times 10^{2} \mathrm{CFU} / \mathrm{mL}$ and $1.362 \pm 0.143 \times$ $10^{5} \mathrm{CFU} / \mathrm{mL}$ respectively, and that can be expressed as 0.0018 to $0.6813 \%$ for the starting viable inoculum (Fig. 4). The average percentages of $20 C$. jejuni and $C$. coli isolated from dogs for adherence to and invasion were $8.67 \times 10^{4}$ 
$\mathrm{CFU} / \mathrm{mL}$ and $8.26 \times 10^{3} \mathrm{CFU} / \mathrm{mL}$, respectively, and that was $0.4335 \%$ and $0.0413 \%$ for the starting viable inoculum (Fig. 4). The average percentages of $20 C$. jejuni and C. coli isolated from humans for adherence to and invasion were $2.29 \times 10^{5}$ $\mathrm{CFU} / \mathrm{mL}$ and $3.94 \times 10^{4} \mathrm{CFU} / \mathrm{mL}$, respectively, and that was $1.1443 \%$ and $0.1971 \%$ for the starting viable inoculum (Fig. 4). Interestingly, C. jejuni and C. coli isolated from humans had more adherence and invasion abilities than these of dogs. $C$. jejuni and $C$. coli isolated from humans are 2.64 times more adherence and 4.77 times more invasive than that of dogs. There was a significant correlation $\left(R^{2}=0.678\right)$ between the adherence ability and the invasion ability of the C. jejuni and C. coli isolates.

\section{Discussion}

This study was performed to investigate the isolation rates of Campylobacter spp. from dogs that assigned into 3 different groups based on their raising conditions (stray, breeding, and household dogs). For comparison of virulence gene prevalence between the isolates of Campylobacter spp. from dogs and humans, PCR was conducted to detect virulence-associated genes including CDT-encoding genes $(c d t \mathrm{~A}, c d t \mathrm{~B}$, and $c d t \mathrm{C}$ ). The expression of CDT activity in the culture supernatants of Campylobacter spp. isolates was tested for cytotoxicity assay with HEp-2 cells. Furthermore, prevalence of GBSassociated genes $(g a l \mathrm{E}, \operatorname{cgt} \mathrm{B}$, wla $\mathrm{N})$ involved in the LOS biosynthesis in $C$. jejuni was compared with the isolates from dogs and humans.

In present study, the isolation rate of Campylobacter in dog was lower than that reported by Hald et al. (76.2\%) [15], however, it was similar to that of Tsai et al. (13.9\%) [31]. The isolation rate was significantly higher in stray dogs (25.2\%) than household dogs (8.8\%). Similarly, Fernandez and Martin [11] found that Campylobacter spp. were isolated more frequently from stray dogs than household dogs. As with the case, $C$. jejuni and $C$. upsaliensis have been demonstrated to be the predominant species in dogs [15], especially in in the household dogs raised in Gyeongnam and Busan areas.

CDT is a bacterial protein toxin that is widely distributed among many Gram-negative bacteria including E. coli strains of many serotypes and some strains belonging to Shigella dysenteriae, Shigella boydii, and various species of Campylobacter [2, 3, 16, 28]. Previously, Park and Richardson [25] revealed that CDT was able to stop proliferation of cell lines. The holotoxin of CDT is consist of three subunits (CdtA, B, C). The CdtB exerts DNase I-like activity, targeting the eukaryotic DNA, thus triggering a signalling pathway involving several protein kinases, hence resulting in the inhibition of the cell cycle in $\mathrm{G} 2$ or $\mathrm{M}$ phase [34]. The genes for CDT production $(c d t \mathrm{~A}, c d t \mathrm{~B}$, and $c d t \mathrm{C})$ were detected as $100 \%$ in the all isolates tested in this study, which is consistent with previous reports by Bang et al. [5] and Asakura et al. [3]. However, despite the high prevalence of $c d t$ genes (100\%), only 26 strains (31.0\%) of C. jejuni and 1 strain (15.3\%) of C. coli isolates showed evidence for CDT production in HEp-2 cell cytotoxicity assays. It is well reported that cytotoxic activity of Campylobacter spp. is susceptible for culture passages in vitro, therefore decrease of toxicity may be due to repeated subculture of isolates in vitro [25]. For a more definitive test of cytotoxic activity, more sensitive methods should be applied to cytotoxicity assays, such as lactate dehydrogenase cytotoxicity (LDH) and 3-(4,5-dimethylthiazol -2-yl)-2,5-diphenyltetrazolium bromide (MTT) colorimetric assay.

Several virulence factors have been documented for Campylobacter spp., which could contribute to its motility, intestinal colonization and invasion. The flagellin gene of Campylobacter spp. has been well characterized. The flaA and fla $\mathrm{B}$ genes constitute the locus of flagellin. Molecular genetic research revealed that fla $\mathrm{A}$ is essential for colonization, but not the fla $\mathrm{B}$ gene [33]. Adhesion of the pathogen to the epithelium is important for colonization of Campylobacter spp. The protein encoded by $c a d \mathrm{~F}$, which binds to fibronectin in the humans gut, $\mathrm{SH}$ group helping the adhesion and invasion $[17,22]$. The $c e u \mathrm{E}$ gene encodes a lipoprotein component of the binding-protein-dependent transport system for the siderophore enterochelin has been identified [27]. Iron acquisition is a crucial aspect of bacterial infectivity and it has been suggested that this system may play an important role in bacterial virulence. Heat shock proteins, especially dnaJ are associated with the environmental thermal response of bacteria which are prominent virulence factors [9]. The $r a c \mathrm{R}$ and $r a c \mathrm{R}-d e p e n d e n t$ genes are important for growth and survival in the avian intestine, and $r a c \mathrm{R}-r a c \mathrm{~S}$ is a signal transduction system responsive to temperature [7].

In this study, fla $\mathrm{A}, c a d \mathrm{~F}, d n a \mathrm{~J}$ and $c e u \mathrm{E}$ genes were detected in the all $C$. jejuni and $C$. coli isolates from dogs and humans. In the previous studies, these genes were detected in almost all isolates from different sources $[9,30]$. The $r a c \mathrm{R}$ genes were detected in the range of $90 \sim 100 \%$ in $C$. jejuni and $C$. coli isolated from dogs and humans in this study, compared to those reports that $r a c \mathrm{R}$ genes were detected in the range of $85.7 \sim 100 \%[4,18]$. The detection rates of the other genes, $c i a \mathrm{~B}, p l d \mathrm{~A}$, $d o c \mathrm{C}$ and $v i r \mathrm{~B} 11$, varied among sources of isolates. The $d o c \mathrm{C}$ gene was found in C. jejuni of human isolates $(19.6 \%)$ that were lower than dog isolates $(37.5 \sim 82.6 \%)$. The virB11 genes were only detected in $C$. jejuni isolated from humans $(6.5 \%)$.

Three GBS-associated genes ( galE, $c g t \mathrm{~B}$ and $w l a \mathrm{~N})$ were detected by $\mathrm{mPCR}$ method, showing that galE gene was detected all $C$. jejuni and $C$. coli isolates. However, cgt $\mathrm{B}$ gene was detected with lesser rate in dog isolates (12.5 $30.4 \%$ in $C$. jejuni and $0 \%$ in $C$. coli) than human isolates (71.7\% in C. jejuni and $75.0 \%$ in C. coli). The wlaN gene was not detected from $C$. jejuni and $C$. coli isolated from dogs, however, in the cases of human isolates, it was detected as 17.4 and $50.0 \%$, respectively. The gal $\mathrm{E}, \operatorname{cgt} \mathrm{B}$ and $w l a \mathrm{~N}$ gene product as $\beta$-1, 3-galactotransferase are responsible for 
specific LOS structure. LOS, similar with gangliosides in neurons, is thought to be critical factor in the triggering of GBS and Miller-Fisher syndrome neuropathies after C. jejuni infection [10, 21, 23]. The higher prevalence of these genes might be associated with GBS in humans.

Animal models that completely mimic Campylobacter infection in humans are not available. INT-407 cells have been used for evaluating the pathogenicity of various enteric pathogens, such as Salmonella enteritidis, C. jejuni, and enteropathogenic $E$. coli $[6,19,24]$. Even though, the process of Campylobacter adhering and invading to INT-407 human intestinal epithelial cells does not exactly mimic the process in vivo during the infection. In this study, the 40 strains of $C$. jejuni and $C$. coli isolates adhered and invade into INT-407 cells by showing variable degree of adherence. The degree of adherence and invasion resulted in this study is similar to the previous report by Biswas et al. [6] that $0.7416 \sim 2.1714 \%$ and $0.0012 \sim 0.4226 \%$ of the range in the adherence and invasion, respectively. Colonization and/or adherence to mucosal surfaces is the primary step of infection and it appears to be a prerequisite for invasion in most pathogens. Therefore, the relationship between adherence and invasion efficiency was analysed with $C$. jejuni and $C$. coli isolates by using statistical tests. There was a significant correlation $\left(R^{2}=0.678\right)$ between the adherence and the invasion ability of the $C$. jejuni and $C$. coli isolates. Thus, the results support the notion that the adherence of $C$. jejuni and C. coli may facilitate invasion into host cells.

\section{Acknowledgments}

This study was supported by a grant for research professor in memorial service year (2011) from Gyeongsang National University, Korea.

\section{References}

1. Allos BM. Campylobcter jejuni infections: update on emerging issues and trends. Clin Infect Dis 2001, 32, 12011206.

2. Anderson JD, MacNab AJ, Gransden WR, Damm SM, Johnson WM, Lior H. Gastroenteritis and encephalopathy associated with a strain of Escherichia coli O55:K59:H4 that produced a cytolethal distending toxin. Pediatr Infect Dis J 1987, 6, 1135-1136.

3. Asakura M, Samosornsuk W, Taguchi M, Kobayashi K, Misawa N, Kusumoto M, Nishimura K, Matsuhisa A, Yamasaki S. Comparative analysis of cytolethal distending toxin $(c d t)$ genes among Campylobacter jejuni, C. coli and C. fetus strains. Microb Pathog 2007, 42, 174-183.

4. Bacon DJ, Alm RA, Burr DH, Hu L, Kopecko DJ, Ewing CP, Trust TJ, Guerry P. Involvement of a plasmid in virulence of Campylobacter jejuni 81-176. Infect Immun 2000, 68, 4384-4390.

5. Bang DD, Scheutz F, Ahrens P, Pedersen K, Blom J, Madsen M. Prevalence of cytolethal distending toxin $(c d t)$ genes and CDT production in Campylobacter spp. isolated from Danish broilers. J Med Microbiol 2001, 50, 10871094.

6. Biswas D, Itoh K, Sasakawa C. Uptake pathways of clinical and healthy animal isolates of Campylobacter jejuni into INT-407 cells. FEMS Immunol Med Microbiol 2000, 29, 203-211.

7. Brás AM, Chatterjee S, Wren BW, Newell DG, Ketley JM. A Novel Campylobacter jejuni two-component regulatory system important for temperature-dependent growth and colonization. J Bacteriol 1999, 181, 3298-3302.

8. Coker AO, Isokpehi RD, Thomas BN, Amisu KO, Obi CL. Human campylobacteriosis in developing countries. Emerg Infect Dis 2002, 8, 237-243.

9. Datta S, Niwa H, Itoh K. Prevalence of 11 pathogenic genes of Campylobacter jejuni by PCR in strains isolated from humans, poultry meat and broiler, and bovine faeces. J Med Microbiol 2003, 52, 345-348.

10. Dingle KE, Van Den Braak N, Colles FM, Price LJ, Woodward DL, Rodgers FG, Endtz HP, Van Belkum A, Maiden MCJ. Sequence typing confirms that Campylobacter jejuni strains associated with Guillain-Barré and MillerFisher syndromes are of diverse genetic lineage, serotype, and flagella type. J Clin Microbiol 2001, 39, 3346-3349.

11. Fernández H, Martin R. Campylobacter intestinal carriage among stray and pet dogs. Rev Saude Publica 1991, 25, 473-475.

12. Florin I, Antillon F. Production of enterotoxin and cytotoxin in Campylobacter jejuni strains isolated in Costa Rica. J Med Microbiol 1992, 37, 22-29.

13. García Roderígez LA, Ruigómez A, Panés J. Acute gastroenteritis followed by an increased of risk of inflammatory bowel disease. Gastroenterology 2006, 130, 1588-1594.

14. Gonzalez I, Grant KA, Richerdson PT, Park SF, Collins MD. Specific Identification of the enteropathogens Campylobacter jejuni and Campylobacter coli by using a PCR test based on the $c e u E$ gene encoding a putative virulence determinant. J Clin Microbiol 1997, 35, 759-763.

15. Hald B, Pedersen K, Wainø M, Jørgensen JC, Madsen M. Longitudinal study of the excretion patterns of thermophilic Campylobacter spp. in young pet dogs in Denmark. J Clin Microbiol 2004, 42, 2003-2012.

16. Johnson WM, Lior H. Production of Shiga toxin and a cytolethal distending toxin (CLDT) by serogroups of Shigella spp. FEMS Microbiol Lett 1987, 48, 235-238.

17. Konkel ME, Gray SA, Kim BJ, Gravis SG, Yoon J. Identification of the enteropathogens Campylobacter jejuni and Campylobacter coli based on the cadF virulence gene and its product. J Clin Microbiol 1999, 37, 510-517.

18. Krutkiewicz A, Klimuszko D. Genotyping and PCR detection of potential virulence genes in Campylobacter jejuni and Campylobacter coli isolates from different sources in Poland. Folia Microbiol 2010, 55, 167-175.

19. Kumar SS, Malladi V, Sankaran K, Haigh R, Williams P, Balakrishnan A. Extrusion of actin-positive strands from Hep-2 and Int 407 cells caused by outer membrane preparations of enteropathogenic Escherichia coli and specific attachment of wild type bacteria to the strands. Can J Microbiol 2001, 47, 727-734.

20. Lastovica AJ, Skirrow MB. Clinical significance of Campylobacter and related species other than Campy- 
lobacter jejuni and C. coli. In: Nachamkin I, Blaser MJ (eds.). Campylobacter. 2nd ed. pp. 89-120, ASM Press, Washington, 2000.

21. Linton D, Gilbert M, Hitshen PG, Dell A, Morris HR, Wakarchuk WW, Gregson NA, Wren BW. Phase variation of a $\beta-1,3$ galactosyltransferase involved in generation of the ganglioside $\mathrm{GM}_{1}$-like lipo-oligosaccharide of Campylobacter jejuni. Mol Microbiol 2000, 37, 501-514.

22. Müller J, Schulze F, Müller W, Hänel I. PCR detection of virulence-associated genes in Campylobacter jejuni strains with differential ability to invade Caco-2 cells and to colonize the chick gut. Vet Microbiol 2006, 113, 123129.

23. Nawaz MS, Wang RF, Khan SA, Khan AA. Detection of galE gene by polymerase chain reaction in campylobacters associated with Guillain-Barre syndrome. Mol Cell Probes 2003, 17, 313-317.

24. Pang JC, Lin JS, Tsai CC, Tsen HY. The presence of major world-wide clones for phage type 4 and 8 Salmonella enterica serovar Enteritidis and the evaluation of their virulence levels by invasiveness assays in vitro and in vivo. FEMS Microbiol Lett 2006, 263, 148-154.

25. Park SF, Richardson PT. Molecular characterization of a Campylobacter jejuni lipoprotein with homology to periplasmic siderophore-binding proteins. J Bacteriol 1995, 177, 22592264.

26. Pickett CL, Pesci EC, Cottle DL, Russell G, Erdem AN, Zeytin H. Prevalence of cytolethal distending toxin production in Campylobacter jejuni and relatedness of Campylobacter sp. $c d t B$ genes. Infect Immun 1996, 64, 2070-2078.

27. Richardson PT, Park SF. Enterochelin acquisition in
Campylobacter coli: characterization of components of a binding-protein-dependent transport system. Microbiology 1995, 141, 3181-3191.

28. Ripabelli G, Tamburro M, Minelli F, Leone A, Sammarco ML. Prevalence of virulence-associated genes and cytolethal distending toxin production in Campylobacter spp. isolated in Italy. Comp Immunol Microbiol Infect Dis 2010, 33, 355-364.

29. Robinson RA, Pugh RN. Dogs, zoonosis and immunosuppression. J R Soc Promot Health 2002, 122, 95-98.

30. Talukder KA, Aslam M, Islam Z, Azmi IJ, Dutta DK, Hossain S, Nur-E-Kamal A, Nair GB, Cravioto A, Sack DA, Endtz HP. Prevalence of virulence genes and cytolethal distending toxin production in Campylobacter jejuni isolates from diarrheal patients in Bangladesh. J Clin Microbiol 2008, 46, 1485-1488.

31. Tsai HJ, Huang HC, Lin CM, Lien YY, Chou CH. Salmonellae and Campylobacters in household and stray dogs in northern Taiwan. Vet Res Commun 2007, 31, 931939.

32. Wassenaar TM. Toxin production by Campylobacter spp. Clin Microbiol Rev 1997, 10, 466-476.

33. Wassenaar TM, van der Zeijst BAM, Ayling R, Newell DG. Colonization of chicks by motility mutants of Campylobacter jejuni demonstrates the importance of flagellin A expression. J Gen Microbiol 1993, 139, 1171-1175.

34. Whitehouse CA, Balbo PB, Pesci EC, Cottle DL, Mirabito PM, Pickett CL. Campylobacter jejuni cytolethal distending toxin causes a $\mathrm{G}_{2}$-phase cell cycle block. Infect Immun 1998, 66, 1934-1940. 